\title{
Effects of Anti-Transpirants and Phosphate Levels on Seed Yield Green Gram (Vigna radiata L.)
}

\author{
Kobagapu Avinash*, Sagar Maitra, Rahul Adhikary and A. Zaman \\ M S Swaminathan School of Agriculture, Centurion University of Technology and \\ Management, Paralakhemundi, Gajapati, Odisha, 761 211, India \\ *Corresponding author
}

\begin{abstract}
Keywords
Green gram, Antitranspirant, Phosphorous level, Yield, Economics

Article Info

Accepted:

04 July 2019

Available Online:

10 August 2019 experimental site is sandy loam in texture. The soil is slightly acidic in reaction (6.2), normal in electrical conductivity, low in organic carbon $(0.41 \%)$, available nitrogen is $76.2 \mathrm{~kg} / \mathrm{ha}$, with 21.3 $\mathrm{kg} / \mathrm{ha}$ of available phosphorus and $126.2 \mathrm{~kg} / \mathrm{ha}$ of available potassium. The experiment was laid out in a Factorial Randomized Block Design with 12-treatment combinations in 3 replications. The first factor was comprised of three levels of sprayings: $S 1=$ no spraying; $S 2=$ single spraying at 25 days after sowing (DAS) i.e. at vegetative stage; S3= double spraying, one at 25 DAS (vegetative stage) another at reproductive stage 50 DAS at full flowering and the second factor was four phosphorous levels, that is $20 \mathrm{~kg} \mathrm{P}_{2} \mathrm{O}_{5} / \mathrm{ha} ; 40 \mathrm{~kg} \mathrm{P}_{2} \mathrm{O}_{5} / \mathrm{ha}$; $60 \mathrm{~kg} \mathrm{P}_{2} \mathrm{O}_{5} /$ ha and $80 \mathrm{~kg} \mathrm{P}_{2} \mathrm{O}_{5} /$ ha. Seeds are sown at a depth of about $3 \mathrm{~cm}$ as per layout plan at a row to row distance of $30 \mathrm{~cm}$ and $10 \mathrm{~cm}$ distance amongst plants was maintained in row. Prior to sowing after final land preparation and layout, the fertilizers were supplied as FYM @ $10 \mathrm{t} / \mathrm{ha}$ and $\mathrm{N}$ and $\mathrm{K}_{2} \mathrm{O}$ were applied @ $20 \mathrm{Kg} / \mathrm{ha}$ each in the form of urea and MOP, respectively. Phosphatic fertilizers as per treatments were applied in the form of SSP in accordance with treatments. Irrespective of phosphorous application the double spray of antitranspirant gave highest plant height $(27.5 \mathrm{~cm})$, Dry matter accumulation $(297.67 \mathrm{~cm})$, Leaf area index (1.61) and grain yield of (865.6 kg/ha) The application of phosphorous@80 kg/ha had shown maximum number of pods per plant (15.96), highest stover yield of $(2059.76 \mathrm{~kg} / \mathrm{ha})$ along with maximum test weight $(2.50 \mathrm{~g})$ and harvest index (29.63). The double spray of anti transpirant along with $80 \mathrm{~kg} / \mathrm{ha}$ had got highest net return and B: C ratio of 1.23 .
\end{abstract}

\section{A B S T R A C T}

The field experiment was conducted during summer season of 2018 at the Bagusala Farm of MS Swaminathan School of Agriculture, Centurion University of Technology and Management, Gajapathi district, Paralakhemundi, Odisha ( $84.18^{\prime} \mathrm{N}$ longitude and 18.80 ' E latitude). The mean minimum and maximum temperatures were $210 \mathrm{C}$ and $310 \mathrm{C}$ respectively. The soil at the

\section{Introduction}

Green gram is an important pulse crop. Historically, India has been the largest global producer and consumer of green gram. It has wider adaptability and low input requirements and the ability to fix the nitrogen in symbiotic association with rhizobia, which not only enables it to meet its own nitrogen requirement but also benefits the succeeding crops. Green gram is a short duration crop that can be grown over a range of environments. It is grown extensively in India under varying soil types and climatic conditions. India alone accounts for about $65 \%$ of the world's acreage and $54 \%$ of the world production of this crop. The important states of India producing this pulse are Madhya Pradesh, Maharashtra, Uttar 
Pradesh, Punjab and Andhra Pradesh, Rajasthan, Karnataka and Tamil Nadu. Despite holding such great promise, green gram is often grown in marginal lands with limited inputs making it prone to a number of abiotic stresses causing tremendous yield loss. For the adaptation of a crop to new environment, tolerance to abiotic stress is more important than the biotic stress. Terminal heat and drought stress may lead to considerable flower drop and thus to reduced pod set. The crop needs a well-distributed rainfall. Heavy rains at flowering are harmful, even moist winds at this stage interfere with fertilization.

Application of antitranspirant in summer gram is beneficial as it checks the moisture loss from the plants (Davenport et al., 1974; Sanbagavalli et al., 2017). Role of phosphorus in legumes needs no over emphasis. It is a constituent of nucleic acid and is present in plants as phosphorylated sugars, nucleoproteins, RNA, DNA, Purine, flavin and thiamine. In plant metabolism, phosphorus plays a direct role as carrier of energy. Earlier researchers recorded beneficial impact of phosphorus application in green gram (Samiullah et al., 1982; Singh et al., 1999).

Considering the above, a field experiments was conducted to study the response of application of antitranspirants and phosphorus levels to summer green gram in south Odisha conditions.

\section{Materials and Methods}

The field experiment was conducted during summer season of 2018 at the Bagusala Farm of MS Swaminathan School of Agriculture, Centurion University of Technology and Management, Gajapathi district, Paralakhemundi, Odisha (84.18'N longitude and $18.80^{\prime} \mathrm{E}$ latitude). The experiment was laid out in a Factorial Randomized Block Design with 12-treatment combinations in 3 replications. The first factor was comprised of three levels of sprayings: $S_{1}=$ no spraying; $S_{2}=$ single spraying at 25 DAS i.e. at vegetative stage; $\mathrm{S}_{3}=$ double spraying, one at 25 DAS (vegetative stage) another at reproductive stage 50 DAS at full flowering and the second factor was four phosphorous levels, that is 20 $\mathrm{kg} \mathrm{P}_{2} \mathrm{O}_{5} / \mathrm{ha} ; 40 \mathrm{~kg} \mathrm{P}_{2} \mathrm{O}_{5} /$ ha; $60 \mathrm{~kg} \mathrm{P}_{2} \mathrm{O}_{5} /$ ha and $80 \mathrm{~kg} \mathrm{P}_{2} \mathrm{O}_{5} / \mathrm{ha}$.

Seeds are sown at a depth of about $3 \mathrm{~cm}$ as per layout plan at a row to row distance of $30 \mathrm{~cm}$ and $10 \mathrm{~cm}$ distance amongst plants was maintained in row. Prior to sowing after final land preparation and layout, the fertilizers were supplied as FYM @ 10 t/ha and $\mathrm{N}$ and $\mathrm{K}_{2} \mathrm{O}$ were applied @ $20 \mathrm{Kg} / \mathrm{ha}$ each in the form of urea and MOP, respectively. $\mathrm{P}_{2} \mathrm{O}_{5}$ as per treatments was applied in the form of SSP in accordance with treatments. The variety of green gram was 'IPM 02-03'. The seed rate was $20 \mathrm{~kg} / \mathrm{ha}$ and row $\mathrm{X}$ plant spacing was maintained at $30 \mathrm{~cm} \times 10 \mathrm{~cm}$. The crop was sown on Mid of February and started harvested from mid-April of 2018through picking of pods.

\section{Soil data}

The soil at the experimental site is sandy loam in texture. The soil is slightly acidic in reaction (6.2), normal in electrical conductivity, low in organic carbon $(0.41 \%)$, available nitrogen is $76.2 \mathrm{~kg} / \mathrm{ha}$, with 21.3 $\mathrm{kg} / \mathrm{ha}$ of available phosphorus and $126.2 \mathrm{~kg} / \mathrm{ha}$ of available potassium (Table 1).

\section{Meteorological parameters}

The mean minimum and maximum temperatures were $21^{\circ} \mathrm{C}$ and $31^{\circ} \mathrm{C}$ respectively. And relative humidity and rainfall was recorded as $90 \%$ and $44.48 \mathrm{~mm}$ respectively (Table 2). 


\section{Results and Discussion}

\section{Effect on growth parameters}

The plant height recorded both at 25 DAS and harvest significantly recorded highest (20.9 $\mathrm{cm}$ and $27.5 \mathrm{~cm}$ respectively) observations when anti-transpirant was sprayed double and dry matter when taken at 50 DAS and harvest had shown highest readings with double spray of anti transpirant $\left(58.65\right.$ and $297.67 \mathrm{~g} / \mathrm{m}^{2} /$ day respectively) whereas the lowest plant height and dry matter was observed with no spray of anti transpirant. The leaf area index at 25 DAS and harvest had shown significantly more leaf area (0.63 and 1.61) when double spray of anti transpirant was followed. Similar findings were observed by Agarwal and De (1977) in which kaolin increased the plant height significantly over control. Kachhadiya et al., (2009) and Lai et al., (1994) found the highest value of leaf area plant after spraying of kaolin than the control

At 25 DAS and harvest the plant height recorded significantly highest $(21.5 \mathrm{~cm}$ and $26.7 \mathrm{~cm}$ respectively).when phosphorous@80 $\mathrm{kg} / \mathrm{ha}$ applied and dry matter when taken at 50 DAS and harvest had shown highest readings with phosphorous@80 kg/ha (61.9 and 293.3 $\mathrm{g} / \mathrm{m} 2 /$ day respectively) whereas the lowest plant height and dry matter was observed with no phosphorous application. The leaf area index at 25 DAS and harvest had shown significantly more leaf area (0.67 and 1.57) when phosphorous applied at $80 \mathrm{~kg} / \mathrm{ha}$. The results obtained were in agreement with Mahetele and Kushwaha (2011) who found that with the increasing levels of phosphorus highest plant height was obtained. Similar results were reported from Meena et al., (2006) and Sengupta and Tamang (2015). Who reported that application of high amount of phosphorus increased dry matter accumulation. Majengo et al., 2011.With the application of phosphorus got the similar results (Table 3 ).

\section{Effect on yield and yield parameters}

The number of pods/plant were significantly recorded highest in double spray of anti transpirant (15.82) at harvest and highest grain and stover yield had been observed significantly highest in treatment with double spray of anti-transpirant (865.6 and 2118.17 $\mathrm{kg} / \mathrm{ha}$ respectively) whereas the lowest number of pods/ plant, grain yield and stover yield number of pods/plant was recorded in no spray of anti transpirant. The highest test weight and harvest index significantly observed highest when double spray of anti transpirant was followed $(2.47 \mathrm{~g}$ and 28.93 respectively). Similar findings were made available from Singh et al., (2000) which showed that the application of antitranspirants increased the pod length and number of pod per plant (Table 4).

Table.1 Physical-chemical properties of experimental soil

\begin{tabular}{|c|c|c|}
\hline Properties & Value & Unit \\
\hline Textural class & Sandy loam & -- \\
\hline Soil reaction (pH) & 6.2 & -- \\
\hline Organic carbon & 0.41 & $\mathbf{\%}$ \\
\hline Electrical conductivity & 0.28 & $\mathbf{d S m}^{-1}$ \\
\hline Available nitrogen & 76.2 & $\mathbf{k g} / \mathbf{h a}$ \\
\hline Available phosphorus & 21.3 & $\mathbf{k g} / \mathbf{h a}$ \\
\hline Available potassium & $\mathbf{1 2 6 . 2}$ & $\mathbf{k g} / \mathbf{h a}$ \\
\hline
\end{tabular}


Table.2 Metrological data during crop period

\begin{tabular}{|c|c|c|c|c|c|c|c|}
\hline \multirow[t]{2}{*}{ Month } & \multicolumn{2}{|c|}{ Temperature $\left({ }^{\circ} \mathrm{C}\right)$} & \multicolumn{2}{|c|}{ Relative humidity (\%) } & \multirow{2}{*}{$\begin{array}{c}\text { Rainfall } \\
(\mathbf{m m})\end{array}$} & \multirow{2}{*}{$\begin{array}{c}\text { ET } \\
(\mathbf{m m})\end{array}$} & \multirow{2}{*}{$\begin{array}{l}\text { BSS } \\
(\mathbf{H r})\end{array}$} \\
\hline & Maximum & Minimum & Morning & Afternoon & & & \\
\hline February, 2018 & 33.9 & 16.9 & 90 & 36 & 0.0 & 9 & 8.76 \\
\hline March, 2018 & 41.4 & 22.0 & 89 & 56 & 102.3 & 104 & 6.6 \\
\hline April, 2018 & 41.8 & 20.8 & 89 & 59 & 32.8 & 127.4 & 7.25 \\
\hline May, 2018 & 41.7 & 21.2 & 92 & 74 & 309.7 & 111.8 & 6.6 \\
\hline
\end{tabular}

Table.3 Effect of anti-transpirant and phosphate levels on plant height, Dry matter accumulation of green gram

\begin{tabular}{|c|c|c|c|c|c|c|}
\hline \multirow[t]{2}{*}{ TREATMENT } & \multicolumn{2}{|c|}{ Plant height (cm) } & \multicolumn{2}{|c|}{$\begin{array}{l}\text { Dry matter accumulation } \\
\left(\mathrm{g} / \mathrm{m}^{2} / \mathrm{day}\right)\end{array}$} & \multicolumn{2}{|c|}{ LAI } \\
\hline & $25 \mathrm{DAS}$ & Harvest & 25 DAS & Harvest & $25 \mathrm{DAS}$ & Harvest \\
\hline \multicolumn{7}{|c|}{ Anti-transpirant } \\
\hline No spray & 20.1 & 23.4 & 57.95 & 278.36 & 0.62 & 1.47 \\
\hline Single spray & 20.8 & 26.7 & 58.45 & 289.34 & 0.63 & 1.52 \\
\hline Double spray & 20.9 & 27.5 & 58.65 & 297.67 & 0.63 & 1.61 \\
\hline SEm \pm & 0.11 & 0.15 & 0.27 & 1.20 & 0.00 & 0.00 \\
\hline $\mathrm{CD}(\mathrm{P}=\mathbf{0 . 0 5})$ & 0.33 & 0.45 & 0.79 & 3.52 & 0.01 & 0.02 \\
\hline \multicolumn{7}{|c|}{ phosphorous level } \\
\hline $20 \mathrm{~kg} \mathrm{ha}^{-1}$ & 19.8 & 25.0 & 53.4 & 281.58 & 0.56 & 1.49 \\
\hline $40 \mathrm{~kg} \mathrm{ha}^{-1}$ & 20.1 & 25.6 & 58.1 & 287.73 & 0.64 & 1.52 \\
\hline $60 \mathrm{~kg} \mathrm{ha}^{-1}$ & 20.8 & 26.1 & 59.9 & 291.22 & 0.65 & 1.55 \\
\hline $80 \mathrm{~kg} \mathrm{ha}^{-1}$ & 21.5 & 26.7 & 61.9 & 293.3 & 0.67 & 1.57 \\
\hline SEm \pm & 0.15 & 0.20 & 0.36 & 1.60 & 0.00 & 0.00 \\
\hline $\mathrm{CD}(\mathbf{P}=\mathbf{0 . 0 5})$ & 0.44 & 0.60 & 1.06 & 4.70 & 0.02 & 0.02 \\
\hline $\mathrm{CV}(\%)$ & 6.57 & 7.10 & 5.59 & 5.00 & 12.78 & 5.57 \\
\hline
\end{tabular}

Table.4 Effect of anti - transpirant and phosphate levels on No of pod plant ${ }^{-1}$, Test weight (g) grain yield, Stover yield and Harvest index of green gram

\begin{tabular}{|c|c|c|c|c|c|}
\hline TREATMENTS & $\begin{array}{l}\text { No of pod } \\
\text { plant }^{-1}\end{array}$ & $\begin{array}{c}\text { Test } \\
\text { weight (g) }\end{array}$ & $\begin{array}{c}\text { Grain yield } \\
\left(\mathrm{kg} \mathrm{ha}^{-1}\right)\end{array}$ & $\begin{array}{l}\text { Stover yield } \\
\left(\mathrm{kg} \mathrm{ha}^{-1}\right)\end{array}$ & Harvest index \\
\hline \multicolumn{6}{|c|}{ Anti-transpirant } \\
\hline No spray & 15.07 & 2.23 & 783.12 & 2008.7 & 28.03 \\
\hline Single spray & 15.5 & 2.34 & 820 & 2081.9 & 28.23 \\
\hline Double spray & 15.82 & 2.47 & 865.6 & 2118.17 & 28.93 \\
\hline SEm \pm & 0.09 & 0.02 & 3.74 & 23.94 & 0.15 \\
\hline $\mathrm{CD}(\mathrm{P}=\mathbf{0 . 0 5})$ & 0.29 & 0.07 & 10.97 & 70.22 & 0.44 \\
\hline \multicolumn{6}{|c|}{ Phosphorous level } \\
\hline $20 \mathrm{~kg} \mathrm{ha}^{-1}$ & 14.96 & 2.17 & 760.7 & 2061.23 & 26.94 \\
\hline $40 \mathrm{~kg} \mathrm{ha}^{-1}$ & 15.33 & 2.32 & 812.16 & 2075.36 & 28.03 \\
\hline $60 \mathrm{~kg} \mathrm{ha}^{-1}$ & 15.6 & 2.40 & 846.2 & 2082.77 & 28.89 \\
\hline $80 \mathrm{~kg} \mathrm{ha}^{-1}$ & 15.96 & 2.50 & 867.56 & 2059.76 & 29.63 \\
\hline SEm \pm & 0.13 & 0.03 & 9.48 & 31.92 & 0.20 \\
\hline $\mathrm{CD}(\mathrm{P}=\mathbf{0 . 0 5})$ & 0.38 & 0.09 & 27.77 & 93.63 & 0.59 \\
\hline CV $(\%)$ & 7.70 & 12.40 & 9.45 & 13.88 & 6.42 \\
\hline
\end{tabular}


Table.5 Effect of anti-transpirant and phosphate levels on Economics of green gram

\begin{tabular}{|c|c|c|c|c|c|}
\hline \multicolumn{5}{|c|}{ ECONOMICS } \\
\hline Treatments & $\begin{array}{c}\text { GRAIN } \\
\text { YIELD kg ha }^{-1}\end{array}$ & $\begin{array}{c}\text { COST OF } \\
\text { CULTIVATION }\end{array}$ & GROSS RETURN & $\begin{array}{c}\text { NET } \\
\text { RETURN }\end{array}$ & B:C RATIO \\
\hline S0P1 & 718 & 20344 & 21540 & 1196 & 1.06 \\
\hline S0P2 & 774 & 20496 & 23220 & 2724 & 1.13 \\
\hline S0P3 & 808 & 20648 & 24240 & 3592 & 1.17 \\
\hline S0P4 & 833 & 20800 & 24990 & 4190 & 1.20 \\
\hline S1P1 & 766 & 21344 & 22980 & 1636 & 1.08 \\
\hline S1P2 & 808 & 21496 & 24240 & 2744 & 1.13 \\
\hline S1P3 & 837 & 21648 & 25110 & 3462 & 1.16 \\
\hline S1P4 & 868 & 21800 & 26040 & 4240 & 1.19 \\
\hline S2P1 & 798 & 22344 & 23940 & 1596 & 1.07 \\
\hline S2P2 & 854 & 22496 & 25620 & 3124 & 1.14 \\
\hline S2P3 & 879 & 22648 & 26370 & 3722 & 1.16 \\
\hline S2P4 & 931 & 22800 & 27930 & 5130 & 1.23 \\
\hline
\end{tabular}

Number of pods/plant were significantly highest when phosphorous @ $80 \mathrm{~kg} / \mathrm{ha}$ (15.96) at harvest and highest grain and Stover yield had been observed significantly highest in treatment with $80 \mathrm{~kg} / \mathrm{ha}$ phosphorous application (867.56 and 2059.76 kg/ha respectively) whereas the lowest number of pods/plant, grain yield and Stover yield number of pods/plant was recorded in no application of phosphorous.

The highest test weight and harvest index (2.50g and 29.63 respectively) significantly observed highest when full dosage of phosphorus was applied $80 \mathrm{~kg} / \mathrm{ha}$.

\section{Effect on economics}

The interaction effect on double spray of antitranspirant along with the application of phosphorous @ $80 \mathrm{~kg} / \mathrm{ha}$ had shown highest net returns (5130 Rs/ha) when compared to other treatments the highest $\mathrm{B}: \mathrm{C}$ ratio (1.23) was also recorded highest in treatment with double spray of anti -transpirant along with the application of phosphorous @ $80 \mathrm{~kg} / \mathrm{ha}$
(Table 5). The double spray of anti-transpirant with application of phosphorous @ $@ 80 \mathrm{~kg} / \mathrm{ha}$ was the best treatment among all other treatments.

\section{References}

Agarwal, S.K. and De, R. (1977). Effect of application of nitrogen, mulching and antitranspirants on the growth and yield of barley under dryland conditions. Indian J. Agric. Sci. 47: 191-194.

Anderson, J.E. and Kreith, F.1978. Effects of film-forming and silicone antitranspirants on four herbaceous plant species, Plant and soil, 49(1): 161-173

Davenport, D.C., Uriu, K. and Hagan, R. M. 1974. Effects of Film Antitranspirants on Growth, Journal of Experimental Botany 25(2): 410-419

Lai, B.; Kaushik, S.K, and Gautam, R.C. (1994). Effect of soil moisture regime, Kaolin spray and phosphorus fertilizer on nodulation, P-uptake and water use 
of lentil (Lens eulinari's). Indian $J$. Agron. 39(2): 241-245.

Mahetele, D., and Kushwaha, H. S. 2011. Productivity and profitability of pigeonpea as influenced by FYM, PSB and phosphorus fertilization under rainfed condition. J. Food Legumes, 24(1): 72-74.

Majengo, C. O., Okalebo, J. R., Lesueur, D., Pypers, P., NG'Etich, W., Mutegi, E., Mburu, M. W. and Musyoki, M. 2011. African Crop Science Society Interaction between nitrogen and phosphorus microbial inoculants on soybean production in Bungoma, Kenya. African Crop Science Conference Proceedings, 10: $121-123$.

Meena, L. R., Singh, R. K. and Gautam, R. C. 2006. Effect of moisture conservation practices, phosphorus levels and bacterial inoculation on growth, yield and economics of chickpea. Legume Res., 29(1): 68-72

Samiullah, A., Akhtar, M., Afridi, M.M.R.K. and Khan, M.M.A. 1982. Effect of basal nitrogen and phosphorus on yield characteristics of summer moong (Vigna radiata var. T-44), Indian $\mathrm{J} . \mathrm{Pl}$. Physiol. 25(1): 27-31.
Sanbagavalli, S., Vaiyapuri, K, Sudhagar, R., Kannan Bapu, J.R. and Ejilane J. 2017. Impact of mulching and antitranspirants on growth and yield of soybean (Glycine max L. Merril), AENSI Journals, 11(1): 84-89.

Schnable, P. S., Ware, D., Fulton, R. S., Stein, J. C., Wei, F., Pasternak, S., and Minx, P. 2009. The B73 maize genome: complexity, diversity, and dynamics. Science, 326(5956), 1112-1115.

Sengupta, K., and Tamang, D. 2015. Response of greengram to foliar application of nutrients and berassinolide. J. Crop Weed, 11(1): 4345.

Singh, M., Singh, Harbir; Singh, T., Jhorar, R.K. and Singh, B.P. 2000. Seed yield, water-use and water-use efficiency of sunflower (H. annuиs) genotypes under irrigation and nitrogen variables. Indian J. Agron. 45(1): 188-192.

Singh, O.P., Tripathi, P.N. and. Singh, R. 1999. Effect of phosphorus and sulphur nutrition on summer greengram (Phaseolus radiatus). Indian J. Agric. Sci. 69(11): 796-799.

\section{How to cite this article:}

Kobagapu Avinash, Sagar Maitra, Rahul Adhikary and Zaman, A. 2019. Effects of AntiTranspirants and Phosphate Levels on Seed Yield Green Gram (Vigna radiata L.). Int.J.Curr.Microbiol.App.Sci. 8(08): 242-247. doi: https://doi.org/10.20546/ijcmas.2019.808.029 